diesen Patientinnen in den pectoralen und axillären Lymphknoten bzw. in den Lymphgefäßen eine markierte Lymphstauung beobachten können. Sie weisen darauf hin, daß das infolge der Lymphstauung entstandene Kollateralen-Netz bei carcinomatösen Fällen schon im Frühstadium eine weitlüufige Metastasenbildung bedingen mag.

\title{
90. Zur Pathogenese akuter gastroduodenaler Erosionen bei der Ratte
}

\author{
A. Larena*, F. Ztmmermani, H.-J. KLEIN und G. HüBner-Köln
}

\section{The Pathogenesis of Acute Gastro-Duodenal Erosions in the Rat}

Summary. To determine the origin of acute erosions in the gastric and duodenal mucosa of the rat we investigated the effect of systemic oxygen deficiency $\left(p \mathrm{O}_{2}\right.$ art. : $60 \mathrm{~mm} \mathrm{Hg}$ ) on the morphology and composition of the gastric juices. $136 \mathrm{Wistar}$ rats were kept in an incubator with an atmosphere of $15 \mathrm{Vol}-\% \mathrm{O}_{2}$ for $1-8$ hours and studied in several groups. After killing the animals the gastric and duodenal preparations were examined macroscopically and by light-microscopy and finestructure examination was also carried out. Morphological changes and lesions of the gastro-duodenal mucosa were present to varying degrees in all animals. Premedication of the animals with the anti-histamine, Tavegil, had a protective effect. On the basis of our results it can be stated that the hypoxaemia itself must be considered as an initial factor. Though our experiments have not produced any definite evidence on the mode of action of hypoxaemia in this respect, there is some evidence due to the hypoxaemia vaso-active substances (histamine) are released or synthesized, which leads to a localized interference with the circulation. In combination with a hypoxydosis of the tissue they cause focal necroses and erosions of the gastric and duodenal mucosa.

Zusammenfassung. Zur Abgrenzung der Entstehungsweise akuter Erosionen in der Magen- und Duodenalschleimhaut der Ratte haben wir den Einfluß eines systemischen Sauerstoffmangels $\left(p \mathrm{O}_{2}\right.$ art. : $60 \mathrm{~mm} \mathrm{Hg}$ ) auf Morphologie und Magensaftzusammensetzung untersucht. 136 Wistar-Ratten wurden mit Hilfe eines Inkubators während 1-8 Std in einer Atmosphäre mit 15 Vol- $\% \mathrm{O}_{2}$ gehalten und in verschiedenen Versuchsserien untersucht. Nach der Tötung erfolgte die makround lichtmikroskopische sowie feinstrukturelle Untersuchung der Magen-Duodenum-Präparate. Bei allen Tieren entstanden unterschiedlich ausgeprägte morphologische Veränderungen und Läsionen in der gastroduodenalen Mucosa. Ein Schutzeffekt konnte durch die Vorbereitung der Tiere mit Antihistaminica (Tavegil) erreicht werden. Auf Grund der Ergebnisse kann gesagt werden, da $B$ die Hypoxämie selbst als initialer Faktor angesehen werden muß. Obwohl unsere Versuche noch keinen eindeutigen Beweis für den Wirkungsmechanismus der Hypoxämie liefern, geben sie dennoch deutliche Hinweise darauf, daß durch die Hypoxämie vasoaktive Substanzen (Histamin) freigesetzt bzw. neugebildet werden, welche zu lokalen Durchblutungsstörungen führen. Diese verursachen im Zusammenhang mit einer Gewebehypoxydose herdförmige Nekrosen und Erosionen in der Magen-Duodenalschleimhaut. 